\title{
ZASTOSOWANIE METODY CSI DO BADANIA SATYSFAKCJI KONSUMENTÓW NA PRZYKŁADZIE WYBRANEJ SIECI HANDLOWEJ
}

\begin{abstract}
Badanie satysfakcji klienta jest obecnie niezbędnym elementem służącym do zdobycia przewagi konkurencyjnej na rynku. W wypadku sektora usług precyzyjna ocena jakości nie jest jednak łatwa, ponieważ zależy od osobistych odczuć klienta. Subiektywizm w ocenie powoduje, że to, co przez jedną osobę jest oceniane bardzo wysoko, dla innej ma charakter przeciętny lub nawet negatywny. Ważnym problemem, który należy wziąć pod uwagę podczas przeprowadzania badań, jest również zrozumienie istoty pojęcia ,jakość postrzegana”. Jakość postrzegana nie zawsze jest równa jakości technicznej. Zależy ona od bardzo wielu zewnętrznych czynników, które często nie mają ścisłego związku z obiektywną oceną doskonałości wykonania. Wynika to z faktu, że każdy konsument na podstawie dostępnych informacji, dotychczasowych doświadczeń czy opinii innych osób wyobraża sobie daną usługę jeszcze przed jej realizacją. W związku z tym głównym celem artykułu był pomiar oczekiwań konsumentów oraz stopnia ich zadowolenia z zakupów w wybranej sieci handlowej. Dążąc do realizacji przyjętego celu, zastosowano metodę Customer Satisfaction Index (CSI), gdzie głównym narzędziem pomiarowym był kwestionariusz ankietowy. Metoda CSI jest jedną z najbardziej popularnych metod służących do pomiaru jakości usług. Pozwala na określenie poziomu satysfakcji oraz ukazuje wiele cennych wskazówek co do kierunku doskonalenia działalności przedsiębiorstw. Badaniem objęto 50 losowo wybranych studentów zamieszkujących miasto Rzeszów oraz dokonujących zakupów w jednej z najbardziej popularnych sieci sklepów dyskontowych. Otrzymane wyniki pozwoliły na przeprowadzenie szczegółowej analizy dotyczącej jakości obsługi oraz przedstawienie propozycji działań doskonalących.
\end{abstract}

Słowa kluczowe: satysfakcja klienta, CSI, jakość usług, sieci handlowe

\section{WPROWADZENIE}

W Polsce w ciągu ostatnich lat zmiany gospodarcze doprowadziły do znacznego nasycenia rynku sieci detalicznych. Ogromna różnorodność produktów oraz szeroki wachlarz możliwości ich pozyskania w znacznym stopniu stymulują wzrost oczekiwań klientów. Cena - do tej pory główny instrument oddziaływania na klienta - nie odgrywa już znaczącej roli w uzyskaniu przewagi nad konkurentami ${ }^{3}$. Również jakość towarów powoli staje się warunkiem oczywistym, przy którym klienci dokonują zakupu danego produktu. Gdy

\footnotetext{
${ }^{1}$ Mgr inż. Joanna Woźniak, Katedra Systemów Zarządzania i Logistyki, Politechnika Rzeszowska, 35-959 Rzeszów, Al. Powstańców Warszawy 10, tel.: 1786510 73, e-mail: j.wozniak@prz.edu.pl (Author for correspondence)

${ }^{2}$ Dr Dominik Zimon, Katedra Systemów Zarządzania i Logistyki, Politechnika Rzeszowska, 35-959 Rzeszów, Al. Powstańców Warszawy 10, tel.: 1786510 73, e-mail: zdomin @ prz.edu.pl

${ }^{3}$ M. Stoma, Modele i metody pomiaru jakości ustug, Q\&R Polska, Lublin 2012, s. 7.
} 
jest ona na niskim poziomie, firma nie ma szans $\mathrm{w}$ walce konkurencyjnej z przedsiębiorstwami z danej branży ${ }^{4}$.

O osiągnięciu i utrzymaniu przez przedsiębiorstwo długookresowego sukcesu w głównej mierze decyduje klient. To on na podstawie własnych odczuć podejmuje decyzje o wyborze danego dobra, a analizując dostępne oferty, szuka dla siebie maksymalnych korzyści. Konieczne staje się więc poszukiwanie przez przedsiębiorstwa nowych „zwabiaczy" dla potencjalnych nabywców. Należy jednak pamiętać, że działania promocyjne mają za zadanie jedynie przyciągnąc klienta, natomiast wysoka jakość obsługi oraz oferowanych produktów zatrzymują go na dłużej.

W ciągu ostatnich dekad można zaobserwować wzrost znaczenia segmentu młodych konsumentów (w wieku 18-24 lat) oraz dostrzeżenia ich odmiennych wymagań i potrzeb w porównaniu z innymi klientami sieci handlowych. Stanowią oni dużą grupę potencjalnych i atrakcyjnych nabywców, charakteryzujących się wysokim stopniem wyedukowania oraz znajomością nowoczesnych technologii ${ }^{5}$. Ponadto osoby te pomimo, że często same nie dokonują zakupów i nie są ostatecznymi użytkownikami wyrobów, wywierają wpływ na decyzje zakupowe innych osób, głównie rodziców. Fakt ten również mobilizuje zarząd przedsiębiorstwa do głębokiej analizy wymagań i potrzeb młodych, potencjalnych konsumentów.

\section{METODA CSI W BADANIACH SATYSFAKCJI KLIENTÓW}

Metoda Wskaźnik Zadowolenia Klienta (CSI, Customer Satisfaction Index ) jest jedną z najbardziej popularnych metod wykorzystywanych do pomiaru jakości usług ${ }^{6}$. Stanowi też doskonałe narzędzie służące do kreowania strategii marketingowej firmy. Pozwala na określenie poziomu satysfakcji oraz stopnia zadowolenia klientów z danego produktu czy usługi. Dzięki niej uzyskuje się odpowiedzi na następujące pytania ${ }^{7}$ :

- jakie są oczekiwania klientów co do oferowanych produktów/usług;

- $\quad$ które z tych oczekiwań mają największe znaczenie dla klienta;

- w jakim stopniu produkty/usługi spełniają te oczekiwania;

- $\quad$ w jakie obszary należy inwestować i je rozwijać, a które z nich są przeinwestowane.

Wskaźnik CSI jest praktycznym narzędziem pomiarowym i ma w sobie wiele zalet, takich jak ${ }^{8}$ :

- łatwość użytkowania metody;

- krótki czas wypełniania ankiety;

- rozpoznanie preferencji i oczekiwań klientów;

- możliwość porównania otrzymanych wyników dla przedsiębiorstw, które ze sobą konkurują;

\footnotetext{
${ }^{4}$ J. Frąś, Wybrane instrumenty pomiaru jakości uslug logistycznych, „Zeszyty Naukowe Uniwersytetu Szczecińskiego" 2014/66.

5 A. Grudecka, Strategie marketingowe sieci detalicznych $w$ kontekście wzrostu znaczenia mtodych konsumentów, „Marketing i Rynek” 2015/11

${ }^{6}$ Obszerny opis metody CSI można znaleźć w: R. Wolniak, B. Skotnicka- Zasadzień, Wybrane metody badania satysfakcji klienta i oceny dostawców w organizacjach, Wydawnictwo Politechniki Śląskiej, Gliwice 2008.

${ }^{7}$ R. Wolniak, B. Skotnicka- Zasadzień, op. cit., s. 77.

${ }^{8} \mathrm{H}$. Hall, Zastosowanie metody NPS I CSI w badaniach poziomu satysfakcji i lojalności studentów, „Modern Management Review"2013/3.
} 
- możliwość systematycznych pomiarów (np. raz do roku).

Wskaźnik Zadowolenia Klienta pozwala na określenie stopnia satysfakcji za pomocą jednej liczby - wyrażonej nominalnie lub procentowo. Wskaźnik CSI wyrażony procentowo można znacznie łatwiej analizować w porównaniu z klasycznym wskaźnikiem CSI. W tym wypadku do interpretacji można się posłużyć kryteriami przedstawionymi w tabeli 1. Należy jednak pamiętać, że kryteria te nie są uniwersalne. Stanowią pewnego rodzaju szkielet, który należy każdorazowo dopasowywać w zależności od potrzeb danej organizacji ${ }^{9}$.

Tabela 1. Kryteria oceny Wskaźnika Zadowolenia Klienta (CSI, Customer Satisfaction Index ) CSI \%

\begin{tabular}{|l|l|}
\hline Kryteria wartości CSI \% & Ocena \\
\hline $0-40 \%$ & Bardzo źle - klient skrajnie niezadowolony \\
\hline $40-60 \%$ & Źle - klient niezadowolony \\
\hline $60-75 \%$ & $\begin{array}{l}\text { Średnio - występują pewne problemy w zakresie } \\
\text { zadowolenia klienta }\end{array}$ \\
\hline $75-90 \%$ & $\begin{array}{l}\text { Dobrze - występują nieliczne problemy z zado- } \\
\text { woleniem klienta }\end{array}$ \\
\hline $90-100 \%$ & $\begin{array}{l}\text { Bardzo dobrze - klient zadowolony w wysokim } \\
\text { stopniu }\end{array}$ \\
\hline
\end{tabular}

Źródło: Opracowanie własne na podstawie: R. Wolniak, B. Skotnicka-Zasadzień, Wybrane metody badania satysfakcji klienta i oceny dostawców w organizacjach, Wydawnictwo Politechniki Śląskiej, Gliwice 2008, s. 80.

Procedura metody CSI zawiera osiem podstawowych etapów, do których zalicza się: określenie klientów badanej firmy, dobór czynników, które mają wpływ na postrzeganie przez klientów oceny jakości produktu/usługi, konstrukcję ankiety, przeprowadzenie badań wśród klientów, opracowanie zebranych danych, obliczenie wskaźnika CSI, graficzne przedstawienie wyników na mapie jakości oraz interpretację wyników ${ }^{10}$.

\section{ANALIZA WYNIKÓW PRZEPROWADZONYCH BADAŃ}

W sierpniu 2015 r. przeprowadzono badania oceny zadowolenia i lojalności klientów w jednej z najbardziej popularnych sieci handlowych. Do realizacji przyjętego celu zastosowano metodę CSI, gdzie głównym narzędziem pomiarowym był kwestionariusz ankietowy składający się z 12 wyszczególnionych obszarów.

Badanie przeprowadzono na grupie 50 studentów zamieszkujących Rzeszów oraz dokonujących zakupów w wybranej sieci sklepów dyskontowych. Dobór próby badawczej wynikał z faktu, że Rzeszów posiada młode społeczeństwo. Według Eurostat Regional

\footnotetext{
${ }^{9}$ R. Wolniak, B. Skotnicka- Zasadzień, op. cit., s. 78-80.

${ }^{10}$ K. Mazurek-Łopacińska, Badania marketingowe. Teoria i praktyka, PWN, Warszawa 2005, s. 473-475.
} 
Yearbook 2012 stolica Podkarpacia cechuje się największym w Europie współczynnikiem ilości studentów do ilości mieszkańców ${ }^{11}$. Fakt ten, bardzo mocno wpływa na rozwój miasta oraz mobilizuje przedsiębiorców i władze samorządowe do realizacji innowacyjnych projektów. Otrzymane wyniki badań mogą więc zostać wykorzystane w praktyce i stanowić cenną wskazówkę dla wszystkich podmiotów oferujących sprzedaż detaliczną.

Respondenci, uzupełniając kwestionariusz, wyrażali swoją opinię w dwóch płaszczyznach: pierwsza dotyczyła stopnia zadowolenia z wykonanej usługi, druga - poziomu istotności danej cechy. Do oceny poszczególnych czynników użyto pięciostopniowej skali typu Likerta, gdzie cyfra 5 oznaczała ocenę najwyższą, cyfra zaś 1 - najniższą. Zebrane kwestionariusze poddano analizie w specjalnie do tego celu opracowanym arkuszu kalkulacyjnym Excel. W tabeli 2 przedstawiono odpowiedzi respondentów dotyczące oceny poszczególnych czynników oraz stopnia ich ważności w wybranej sieci handlowej.

Jak wynika z przeprowadzonych badań (Tabela 2), respondenci najkorzystniej ocenili możliwość korzystania z różnych form płatności - wynik kształtuje się na poziomie 4,5. Najgorzej zaś wypadł obszar związany z programami lojalnościowymi, w którym wartość wynosi 2,94. Może to wynikać z tego, że badana sieć handlowa nie ma w swojej ofercie żadnych dodatkowych rabatów czy zniżek dla stałych klientów, które aktualnie są popularne w innych konkurencyjnych sklepach.

Analizując poziom istotności, okazuje się, że najważniejsze znaczenie dla respondentów mają kolejno: możliwe formy płatności $(4,46)$, jakość $(4,42)$ oraz dostępny asortyment $(4,32)$. Dopiero na czwartym miejscu ankietowani jako ważną określili cenę towaru $(4,24)$. Jako najmniej istotne zostały ocenione merchandising $(3,42)$ oraz programy lojalnościowe $(3,24)$.

\footnotetext{
11 Eurostat, Focus on European cities, Luxembourg: Publications Office of the European Union 2012, http://ec.europa.eu/eurostat/documents/3217494/5735109/KS-HA-12-001-12-EN.PDF/7fe23280-0753-487993bd-4b5878fae0b4?version=1.0, [dostęp: 23.01.2016]
} 
Tabela 2. Przedstawienie szczegółowej analizy wszystkich dwunastu obszarów

\begin{tabular}{|c|c|c|c|c|c|c|c|c|c|c|c|c|}
\hline \multirow{4}{*}{ 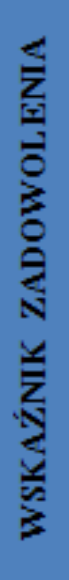 } & \multicolumn{11}{|c|}{ WYNIKI BADAN } & \multirow{4}{*}{ 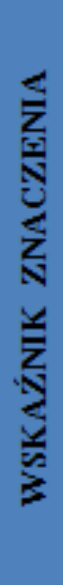 } \\
\hline & \multicolumn{5}{|c|}{ ZADOWOLENIE } & \multirow{3}{*}{$\begin{array}{c}\text { CZYNNIKI } \\
\text { SATYSFAKCJI }\end{array}$} & \multicolumn{5}{|c|}{ ZNACZENIE } & \\
\hline & 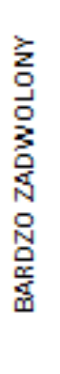 & 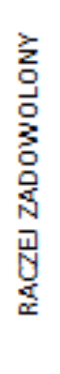 & 芝 & 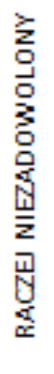 & 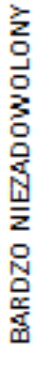 & & 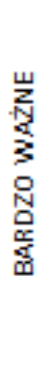 & $\stackrel{w}{\geq}$ & 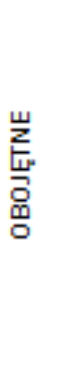 & 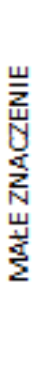 & 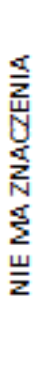 & \\
\hline & 5 & 4 & 3 & 2 & 1 & & 5 & 4 & 3 & 2 & 1 & \\
\hline 4,22 & 13 & 35 & 2 & 0 & 0 & CENA & 13 & 36 & 1 & 0 & 0 & 4,24 \\
\hline 3,82 & 7 & 30 & 10 & 3 & 0 & JAKOŚĆ & 25 & 22 & 2 & 1 & 0 & 4,42 \\
\hline 4,04 & 11 & 31 & 7 & 1 & 0 & ASORTYMENT & 20 & 26 & 4 & 0 & 0 & 4,32 \\
\hline 3,5 & 4 & 23 & 18 & 4 & 1 & ESTETYKA SKLEPU & 5 & 24 & 17 & 3 & 1 & 3,58 \\
\hline 3,86 & 5 & 37 & 4 & 4 & 0 & $\begin{array}{c}\text { WYGODA } \\
\text { ZAKUPOW }\end{array}$ & 11 & 28 & 8 & 2 & 1 & 3,92 \\
\hline 3,78 & 10 & 21 & 17 & 2 & 0 & MERCHANDISING & 5 & 21 & 17 & 4 & 3 & 3,42 \\
\hline 4,06 & 14 & 26 & 9 & 1 & 0 & $\begin{array}{c}\text { AKCJA } \\
\text { PROMOCYJNA } \\
\end{array}$ & 12 & 24 & 12 & 2 & 0 & 3,92 \\
\hline 4,5 & 32 & 11 & 7 & 0 & 0 & FORMY PLATNOŚCI & 30 & 14 & 5 & 1 & 0 & 4,46 \\
\hline 2,94 & 3 & 7 & 27 & 10 & 3 & $\begin{array}{c}\text { PROGRAMY } \\
\text { LOJALNOSCIOWE }\end{array}$ & 7 & 8 & 27 & 6 & 2 & 3,24 \\
\hline 3,66 & 3 & 30 & 15 & 1 & 1 & $\begin{array}{l}\text { PROFESJONALIZM } \\
\text { PRACOWNIKOW }\end{array}$ & 14 & 27 & 8 & 1 & 0 & 4,08 \\
\hline 3,4 & 4 & 15 & 28 & 3 & 0 & $\begin{array}{l}\text { OBSLUGA } \\
\text { REKLAMACJI } \\
\text { I SKARG } \\
\end{array}$ & 14 & 23 & 12 & 1 & 0 & 4,0 \\
\hline 3,54 & 8 & 21 & 12 & 8 & 1 & $\begin{array}{c}\text { DOSTEPNOŚĆ } \\
\text { MIEJSC } \\
\text { PARKINGOWYCH } \\
\end{array}$ & 18 & 21 & 10 & 1 & 0 & 4,12 \\
\hline
\end{tabular}

Źródło: opracowanie własne.

Kolejnym etapem obliczeń jest wyznaczenie tak zwanej wagi względnej dla poszczególnych wskaźników. W celu lepszej interpretacji wyników obliczono również wartość maksymalną, którą z kolei przekształcono na wartość procentową. Obliczenie wskaźników CSI, CSI max oraz CSI \% dla wybranej sieci handlowej przedstawiono w tabeli 3. 
Tabela 3. Obliczenie Wskaźnika Zadowolenia Klienta (CSI, Customer Satisfaction Index ), CSI max oraz CSI \%

\begin{tabular}{|c|c|c|c|c|c|c|}
\hline $\begin{array}{c}\text { CZYNNIKI } \\
\text { SATYSFAKCJI }\end{array}$ & $\begin{array}{c}\text { OCENA } \\
\text { CZYNNIKA }\end{array}$ & $\begin{array}{c}\text { WAGA } \\
\text { CZYNNIKA }\end{array}$ & $\begin{array}{c}\text { WAGA } \\
\text { WZGLĘDNA }\end{array}$ & $\begin{array}{l}\text { WSKAŹNIK } \\
\text { CSI }\end{array}$ & $\begin{array}{l}\text { CSI } \\
\text { MAX }\end{array}$ & \\
\hline CENA & 4,22 & 4,24 & 0,089 & 0,375 & 0,444 & \\
\hline JAKOŚĆ & 3,82 & 4,42 & 0,093 & 0,354 & 0,463 & \\
\hline ASORTYMENT & 4,04 & 4,32 & 0,091 & 0,366 & 0,453 & \\
\hline ESTETYKA SKLEPU & 3,5 & 3,58 & 0,075 & 0,263 & 0,375 & \\
\hline WYGODA ZAKUPÓW & 3,86 & 3,92 & 0,082 & 0,317 & 0,411 & \\
\hline MERCHANDISING & 3,78 & 3,42 & 0,072 & 0,271 & 0,358 & \\
\hline $\begin{array}{c}\text { AKCJA } \\
\text { PROMOCYJNA }\end{array}$ & 4,06 & 3,92 & 0,082 & 0,334 & 0,411 & \\
\hline FORMY PLATNOŚCI & 4,5 & 4,46 & 0,093 & 0,421 & 0,467 & \\
\hline $\begin{array}{c}\text { PROGRAMY } \\
\text { LOJALNOŚCIOWE }\end{array}$ & 2,94 & 3,24 & 0,068 & 0,200 & 0,339 & \\
\hline $\begin{array}{c}\text { PROFESJONALIZM } \\
\text { PRACOWNIKÓW }\end{array}$ & 3,66 & 4,08 & 0,085 & 0,313 & 0,427 & \\
\hline $\begin{array}{c}\text { OBSLUGA } \\
\text { REKLAMACJI } \\
\text { I SKARG } \\
\end{array}$ & 3,4 & 4 & 0,084 & 0,285 & 0,419 & \\
\hline $\begin{array}{c}\text { DOSTEPPNOSC } \\
\text { MIIJSC } \\
\text { PARKINGOWYCH }\end{array}$ & 3,54 & 4,12 & 0,086 & 0,306 & 0,432 & \\
\hline \multirow{2}{*}{ 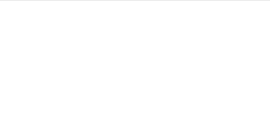 } & & \multirow[t]{2}{*}{$\Sigma=47,72$} & & CSI & $\begin{array}{l}\text { CSI } \\
\max \end{array}$ & CSI $\%$ \\
\hline & & & & 3,802 & 5 & $76 \%$ \\
\hline
\end{tabular}

Źródło: opracowanie własne.

Po przeanalizowaniu otrzymanych wyników stwierdzono, że oczekiwania klientów wybranej sieci dyskontowej można uznać za zadowalające. Wskaźnik CSI \% w tym przypadku wynosi $76 \%$.

Należy jednak pamiętać, że rynek sieci dyskontowych charakteryzuje się dużą konkurencją. W celu zapewnienia przywiązania i lojalności klientów przedsiębiorstwo musi stale podnosić jakość oferowanych dóbr i usług. Warto również zwrócić uwagę na to, że wymagania konsumentów mają dynamiczny charakter. Zmiany w gustach i upodobaniach zachodzą nie tylko pod wpływem dotychczasowych doświadczeń, ale również obserwacji zachowań konkurencji.

Reasumując, można stwierdzić, że jakość oferowanych usług znajduje się na wysokim poziomie. Mimo to przedsiębiorstwo powinno stale udoskonalać wszystkie aspekty swojej działalności oraz rozpocząć działania mające na celu budowanie stałych relacji z klientami. 


\section{OPRACOWANIE MAPY JAKOŚCI}

W dalszej części badań zebrany materiał zobrazowano na mapie pozycjonującej. Działanie to polega na naniesieniu ważności danego czynnika na osi poziomej oraz na ocenie zadowolenia klientów na osi pionowej. Opisana technika graficzna pozwoliła wyodrębnić cztery obszary. W ten sposób otrzymano informację o tym, jakie aspekty należy jak najszybciej poprawić, jakie powinny zostać udoskonalone, jakie mogą pozostać w obecnym stanie, a także które $\mathrm{z}$ nich są najmniej istotne ${ }^{12}$.

Pierwszy etap budowy mapy jakości polega na wyznaczeniu punktów jej podziału. Opracowanie wyników przedstawiono w tabeli 4.

Tabela 4. Wyznaczenie punktów podziału mapy jakości dla wybranej sieci handlowej

\begin{tabular}{|c|c|c|}
\hline CZYNNIKI SATYSFAKCJI & Waga czynnika & Ocena czynnika \\
\hline CENA & 4,24 & 4,22 \\
\hline JAKOŚĆ & 4,42 & 3,82 \\
\hline ASORTYMENT & 4,32 & 4,04 \\
\hline ESTETYKA SKLEPU & 3,58 & 3,5 \\
\hline WYGODA ZAKUPÓW & 3,92 & 3,86 \\
\hline MERCHANDISING & 3,42 & 3,78 \\
\hline AKCJA PROMOCYJNA & 3,92 & 4,06 \\
\hline FORMY PLATNOŚCI & 4,46 & 4,5 \\
\hline PROGRAMY LOJALNOŚCIOWE & 3,24 & 2,94 \\
\hline PROFESJONALIZM PRACOWNIKÓW & 4,08 & 3,66 \\
\hline OBSLUGA REKLAMACJI I SKARG & 4,00 & 3,4 \\
\hline DOSTĘPNOŚĆ MIEJSC PARKINGOWYCH & 4,12 & 3,54 \\
\hline Średnia & $\mathbf{4 , 0}$ & $\mathbf{3 , 8}$ \\
\hline
\end{tabular}

Źródło: opracowanie własne.

Na podstawie otrzymanych wyników z tabeli 5 mapę jakości podzielono na cztery części. Punkty podziału w tym wypadku wynoszą: 4,0 na osi ważności oraz 3,8 na osi satysfakcji. Graficzne przedstawienie wyników zaprezentowano na rysunku 1.

\footnotetext{
${ }^{12}$ D. Zimon, U. Kruk, Wykorzystanie metody CSI do badania logistycznej obstugi klienta na przykladzie wybranej organizacji, „Logistyka” 2015/3.
} 
Rys. 1. Mapa jakości dla badanej sieci handlowej

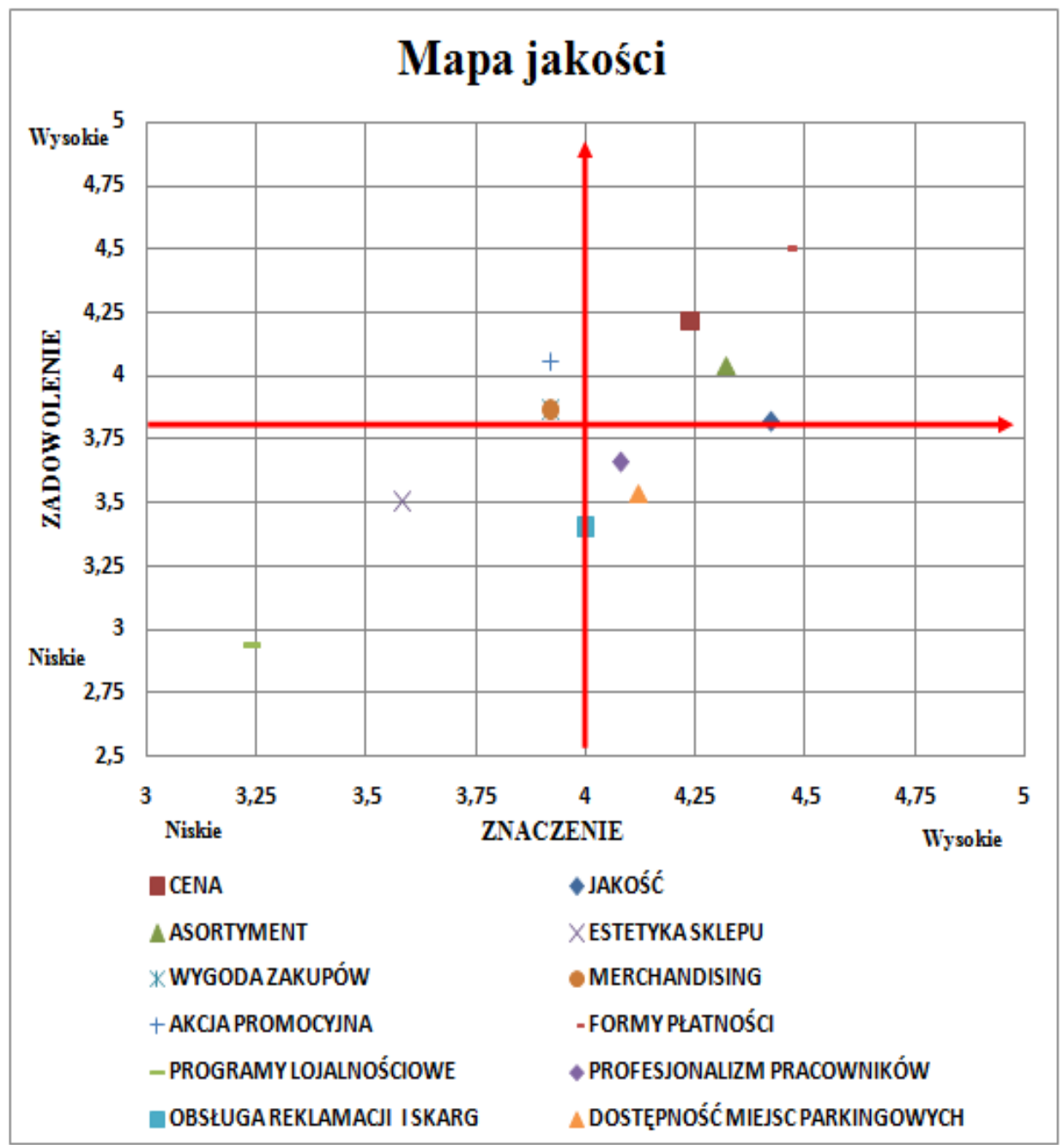

Źródło: opracowanie własne.

Analizując otrzymane wyniki, można stwierdzić, że:

- mocną stroną wybranej sieci handlowej są: możliwe formy płatności, cena oraz dostępny asortyment - te obszary należy utrzymać na obecnym poziomie;

- jakość towarów znajduje się na granicy zadowolenia klientów - ten aspekt należy stale kontrolować i udoskonalać;

- obszary, na które należy zwrócić szczególną uwagę oraz poprawić je w jak najkrótszym czasie, to: dostępność miejsc parkingowych oraz profesjonalizm pracowników;

- pewnej poprawy wymagają: programy lojalnościowe, estetyka sklepu oraz obsługa reklamacji i skarg; 
- $\quad$ merchandising, akcje promocyjne oraz wygoda zakupów spełniają oczekiwania klientów, jednak nie są to najważniejsze czynniki podczas dokonywania zakupów.

\section{WNIOSKI}

Na podstawie badań i analizy literatury można stwierdzić, że badanie satysfakcji klienta jest niezwykle istotne w kontekście działalności przedsiębiorstw. Zastosowana metoda CSI umożliwiła identyfikację zarówno poziomu satysfakcji, jak i lojalności konsumentów wybranej sieci handlowej. Przeprowadzone w artykule analizy pozwoliły na sformułowanie następujących wniosków:

- $\quad$ klient oraz jego obsługa powinny się stać kluczowymi obszarami zainteresowań współczesnych organizacji;

- $\quad$ badania satysfakcji klienta pozwalają na ukazanie mocnych i słabych stron działalności przedsiębiorstw;

- dla klientów dokonujących zakupów w sieciach handlowych najważniejsze są: możliwe formy płatności, jakość towarów, dostępny asortyment oraz jego cena;

- $\quad$ konsumenci jako najmniej istotne wskazali obszary związane z programami lojalnościowymi, merchandisingiem, estetyką sklepu oraz jego promocją.

Do podobnych wniosków doszedł Dominik Zimon wraz z współautorami ${ }^{13}$ po przeprowadzeniu badań nad wpływem jakości produktów na zachowania konsumentów. Udowodniono wówczas, że najważniejsze znaczenie dla nabywców podczas dokonywania zakupów mają jakość i cena towaru, natomiast reklama została wskazana jako jeden z najmniej istotnych czynników. Ponadto zaobserwowano, że wysoka jakość oferowanych produktów ma bardzo duży wpływ na osiągnięcie przez organizację sukcesu i przewagi konkurencyjnej.

Reasumując, należy stwierdzić, że istotną funkcją zarządzania każdej organizacji jest stałe ocenianie i kontrolowanie czynności w niej zachodzących, a metody i narzędzia zarządzania jakością są niewątpliwie elementami wspierającymi te działania.

\section{LITERATURA}

[1] Frąś J., Wybrane instrumenty pomiaru jakości ustug logistycznych, „Zeszyty Naukowe Uniwersytetu Szczecińskiego" 2014/66.

[2] Grudecka A., Strategie marketingowe sieci detalicznych w kontekście wzrostu znaczenia młodych konsumentów, „Marketing i Rynek”, 2015/11

[3] Hall H., Zastosowanie metody NPS i CSI w badaniach poziomu satysfakcji i lojalności studentów, „Modern Management Review” 2013/3.

[4] Mazurek-Łopacińska K., Badania marketingowe. Teoria i praktyka, PWN, Warszawa 2005.

[5] Stoma M., Modele i metody pomiaru jakości ustug, Q\&R Polska, Lublin 2012.

[6] Wolniak R., Skotnicka-Zasadzień B., Wybrane metody badania satysfakcji klienta $i$ oceny dostawców w organizacjach, Wydawnictwo Politechniki Śląskiej, Gliwice 2008.

[7] Zimon D., Gawron- Zimon Ł., Szczygieł K., Wpływ jakości produktów na zachowania konsumentów, „Kwartalnik Nauk o Przedsiębiorstwie” 2014/4.

[8] Zimon D., Kruk U., Wykorzystanie metody CSI do badania logistycznej obstugi klienta na przyktadzie wybranej organizacji, „Logistyka” 2015/3.

\footnotetext{
${ }^{13}$ D. Zimon, Ł. Gawron- Zimon, K. Szczygieł, Wplyw jakości produktów na zachowania konsumentów, „Kwartalnik Nauk o Przedsiębiorstwie” 2014/4.
} 
[9] Eurostat, Focus on European cities, Luxembourg: Publications Office of the European Union 2012, http://ec.europa.eu/eurostat/documents/3217494/5735109/KS-HA-12-001-12-

EN.PDF/7fe23280-0753-4879-93bd-4b5878fae0b4?version=1.0, [dostęp: 23.01.2016]

\section{APPLICATION OF CSI METHOD TO RESEARCH SATISFACTION OF CON- SUMER IN SELECTED SALES NETWORK}

Study of customer satisfaction is currently necessary component to gain competitive advantage in the market. In the case of the services sector precise assessment of quality is not easy, because it depends on the personal customer experience. Subjectivism in the assessment causes that the same thing can be rated very high by one person but for the others it can be ordinary and even negative. Very important problem which we should undertake during the study is also the understanding of the concept of "perceived quality". Perceived quality is not always equal to the technical qualities. It depends on many external factors which often do not have a close relationship with an objective assessment of performance excellence. It follows that every consumer based on available information, past experience or the opinions of others, imagine the service before its realization. The main purpose of the article is measuring consumer expectations and degree of satisfaction with shopping in selected commercial network. Seek to realization of the objectives pursued used to CSI method in which measuring tool was questionnaire. CSI is one of the most popular methods of measuring the quality of services. It allows to determine the level of satisfaction and reveals many valuable clues which concern the direction of improvement of companies. The study included 50 students lives in Rzeszow and makes purchases in one of the most popular discount store. The results allowed to detailed analysis of quality of service and present proposals for improvement activities.

Keywords: customer satisfaction, CSI, service quality, sales network

DOI: $10.7862 /$ rz.2016.mmr.37

Tekst złożono w redakcji: kwiecień 2016

Przyjęto do druku: sierpień 2016 